\title{
Natural regeneration of trees in urban woodlands
}

\author{
Lehvävirta, S.
}

Opulus Press

2002

Lehvävirta, S. and Rita, H. 2002. Natural regeneration of trees in urban woodlands. Journal of Vegetation Science 13: 57-66.

http://hdl.handle.net/1975/255

Downloaded from Helda, University of Helsinki institutional repository.

This is an electronic reprint of the original article.

This reprint may differ from the original in pagination and typographic detail.

Please cite the original version. 


\title{
Natural regeneration of trees in urban woodlands
}

\author{
Lehvävirta, Susanna* \& Rita, Hannu \\ Department of Ecologv and Sustematics. P.O.B. $17, F I N-000) 1+$ University of Helsinki. Finland; \\ "Corresponding author; E-mail susannalehvavirta ahelsinkifi
}

\begin{abstract}
We studied tree regeneration. a key process for the existence of urban woodlands. We hypothesized that. besides the usual biological factors. anthropogenic ones (fragmentation. wear. pollution etc.) determine the regeneration success of tree species in urban woodlands. To test this hypothesis. within an obscrvational setting, we collected data from 30 urban woodlands in the cities of Helsinki and Vantaa, Finland. We defined the number of living saplings $(30-200 \mathrm{~cm}$ in height) as an indicator of regeneration success and used regression analysis to test different factors as independent variables. The results showed that different tree species responded differently to urban pressure. The regeneration of Picea abies decreased with increasing fragmentation of the forest landscapc. whereas for the other most common (deciduous) species. regencration increased. Wear. measured as total path area per study site. had a negative effect on regeneration success. An a posteriori examination of the data suggested that coarse woody debris might promote regeneration. We conclude that although tree regeneration in general is not threatened in urban woodlands in the area we studied, the species composition may gradually change. We discuss some management implications for counteracting the urban pressures on tree regeneration.
\end{abstract}

Keywords: Acer platanoides; Anthropogenic effect; Betula spp: Fragmentation: Management; Picea abies; Pollution: Populus tremula: Sorbus aucuparia: Wear.

Nomenclature: Hätnet-Ahti et al. 1992.

\section{Introduction}

Human activities cause severe changes in ecosystems worldwide. In urban areas, these changes - for example fragmentation of forest landscapes, pollution, wear and the introduction of new species - are excessive (Rebele 1994; Breuste et al. 1998). Hence, urban woodlands offer an opportunity to study the effect of various anthropogenic factors and the viability of forest ecosystems in extreme conditions (McDonnell \& Pickett 1990; McDonnell et al. 1997).

The terminology concerning urban forest ecosystems is diverse and evolving (Konijnendijk 1997; Rydberg \& Falck 1998; Tyrväinen 1999). Here, 'urban woodland' indicates indigenous forest stands of any size, within or in the surroundings of a city. In a wood- land, field and ground layer vegetation is not managed as in a park and stand structure is more similar to that of a natural forest than a park. Forest is used as a general term, referring to the frameworks of forest ecology and urban forestry.

The natural dynamics of urban woodlands has been a neglected research subject, perhaps because of the prevailing assumption that urban woodlands 'need' management, and because urban ecology has been deemed 'uninteresting' (Niemelä 1999). Now, worldwide urbanization and growing awareness of environmental issues challenge scientists to re-evaluate the present knowledge and management strategies (Konijnendijk 1997). It is essential to recognize the disturbance agents and understand the processes operating in urban woodlands, if we want to know how to manage (or not to manage) them sustainably. The negative effect which forestry may have on biodiversity (Heliövaara \& Väisänen 1984; Rassi \& Väisänen 1987; Bader et al. 1995; Renvall 1995; Niemelä 1997) adds to the importance of critically re-evaluating the way we treat our woods.

The effect of air pollution on woodland vegetation in the Greater Helsinki area has been monitored since 1988 (Pihlström et al. 1994; Niskanen et al, 1996). Many indicators of air pollution (e.g. needle loss of conifers and heavy metal contents in mosses) show a gradient from the centre of Helsinki towards the surroundings. It is a common belief among urban foresters in Finland that pollution, wear and vandalism suppress regeneration. especially in old Picea abies dominated forests. Indeed, a negative effect of recreational use on regeneration has been reported elsewhere (Tonnesen \& Ebersole 1997; Bhuju \& Ohsawa 1998). However, no data exist on regeneration of trees in woodlands in Helsinki and the surroundings, although regrowth is essential for the existence of the ecosystem in the long term.

Here, we aimed to (1) describe the amount of regeneration in urban woodlands, (2) test, with observational data, a priori hypotheses about factors affecting regeneration success of trees, and (3) a posteriori explore data for more details. Our design was not experimental, but with restrictions, hypotheses can also be tested within an observational setting (Cook \& Campbell 1979). We 
wanted to clearly distinguish hypothesis testing from blind exploration, and thus treat them separately.

When studying urban ecology, we can assume that ecological processes in urban areas are similar to those in rural environments (Niemelä 1999). Thus, we based our theoretical framework and hypotheses of regeneration on knowledge gained from both urban and rural forest ecosystems as follows. We hypothesized that in similar urban woodland sites, the regeneration success of trees is determined by:

(1) a positive effect of availability of regeneration sources for sprouting or recruitment from seeds (Johnson et al. 1981: Ranney et al. 1981; Zasada et al. 1992);

(2) a negative effect from decrease in growing space (Kuuluvainen et al. 1993; Oliver \& Larson 1996);

(3) species-specific effects of altered light and climate conditions, following fragmentation of the forest landscape, (Levenson 1981; Ranney et al. 1981; Saunders et al. 1991);

(4) a negative effect of the amount of wear (Tonnesen \& Ebersole 1997; Bhuju \& Ohsawa 1998);

(5) species-specific effects of other anthropogenic disturbances such as creation of new substrates or dog fouling (Bullock \& Gregory 1991; Shaw et al. 1995):

(6) a positive effect of the availability of favourable microsites for regeneration (Hofgaard 1993; Kuuluvainen 1994: Tonnesen \& Ebersole 1997; Lehvävirta 1999) and

(7) species-specific effects of air pollution (Scholz 1981; Väisänen 1986: Prus-Glowacki \& Godzik 1991: Larcher 1995).

\section{Material and Methods}

Siludy sites

The study was conducted in the adjacent cities of Helsinki and Vantaa, Finland. The area $\left(60^{\circ} \mathrm{N}, 24^{\circ} \mathrm{E}\right)$ belongs to the hemiboreal vegetation zone (Ahti et al. 1968), and contains broad-leaved deciduous and coniferous forests. Helsinki (population 540000 ) covers an area of $185 \mathrm{~km}^{2}$ and Vantaa (population 171000 ) an area of $243 \mathrm{~km}^{2}$ (Anon. 1998).

We searched for sites of medium fertility (Myrtillustype) on coarse or semi-coarse moraine from Helsinki and Vantaa Cities' Green Area Divisions forest inventory data. We examined 158 forest compartments, older than $84 \mathrm{yr}$, and classified them according to management intensity (method adapted from Lindholm \& Tuominen 1993). To minimize the effects of management on regeneration, we chose the 30 most natural ones as study sites.

The dominant trees in the sites were $85-150 \mathrm{yr}$ old, with a mean dbh of $24-55 \mathrm{~cm}$, a stem density of $70-570$ ha-1, and a basal area of $8-26 \mathrm{~m}^{2} \mathrm{ha}^{-1}$. Picea abies was usually the most numerous species, but Pimus sv/vestris and Betula pendula were also common. Other species in the dominant tree layer were Populus tremula. Sortus aucuparia, Acer platanoides and Betula pubescens. The study sites (forest compartments) varied in size from 0.2 to $2 \mathrm{ha}$, and were located along a gradient from small isolated patches $(0.2 \mathrm{ha})$ to large continuous woodland areas (up to $500 \mathrm{ha}$ ). The number of inhabitants and the presence of schools and kindergartens varied in the surroundings of the sites (Vuori 1998).

\section{Measurements}

We examined 8 (in the smallest sites $<8$ but minimally 5) random plots of $5 \mathrm{~m} \times 6 \mathrm{~m}$ in the 30 study sites in July-August 1997. Most of the plots were placed at least $5 \mathrm{~m}$ from each other and the site edge. The numerous saplings and small trees $(<2 \mathrm{~cm} \mathrm{dbh)} \mathrm{of} \mathrm{Sorbus}$ aucuparia were measured in a subplot of $1 \mathrm{~m} \times 5 \mathrm{~m}$.

In the sample plots, we counted living saplings (30$200 \mathrm{~cm}$ in height) and recorded the species. Shoots growing closer than $50 \mathrm{~cm}$ from each other were counted as one individual, if they could be identified as root suckers. Only every second individual exactly at the plot edge was noted. Other data collection on the plots included $\mathrm{dbh}$; horizontal length or largest diameter of all structural elements, including stones, topography, fallen trees and all other measurable structures at least $30 \mathrm{~cm}$ high; area and level of wear of spontaneous paths (Lehvävirta 1999).

\section{Logic of testing}

We used the number of saplings (height $30-200 \mathrm{~cm}$ ) per study site as an indicator of regenerative success. This was determined for Picea abies, Sorbus ancuparia, Populus tremula, Acer platanoides, Betula spp. (including pubescens and pendula), all the other species pooled and the total number of all saplings. The group 'other species' consisted of species with too few observations to be studied individually. The numbers of saplings were subjected to $\log _{10}(x+1)$-transformation.

We used linear regression models to test our hypotheses statistically (software Statistix 7; Anon. 1996). There, the significance of variables is tested using individual $t$-tests, for which the hypothesis can be stated loosely as, "does the variable under test give information (on the behaviour of the response variable) in addition to the variables already included in the model'. One cannot speak about the significance of a variable in any absolute sense: the variables present in the model determine the interpretation of the test result of a single 
variable (Weisberg 1985; Kerlinger 1986). We made use of this by testing each independent hypothesis in an appropriate model (Table 1; for precise description of variables, see Table 2), thus providing a logically more sound test setting than in an ordinary all-in-one -model.

The first group of hypotheses (I) concerned the effects of available regeneration sources, growing space and forest fragmentation. While PARENTS indicate potential regeneration sources, PARENTS SQ allows a curvilinear relationship, and signifies limitation in growing space, together with OTHER TRFES. FOREST AREA indicates changes in climatic and light conditions due to fragmentation. The adjusting variables were in the model to control for the possible effects of wear and safe sites.

The second group of hypotheses (II) concerned the effect of wear and availability of favourable microsites for regeneration. Wear was measured indirectly by usFRS. favourable microsites by BARRIFRS and BARRIERS SQ. To adjust for ecological differences between sites, we included the variables signifying regeneration sources, growing space and fragmentation in the model. For further specification of the hypothesis, FOREST AREA was dropped from the model to test whether it affected the results for tSERS.

The hypothesis (III) concerned anthropogenic disturbances other than actual wear. The appropriate model included all of the variables that were in model (II) plus PATH AREA, to test the behaviour of USERS when adjusting for wear.

The next hypothesis (IV) concerned the effect of actual wear, as measured directly by PATH AREA. We expected PAII AREA to be affected by USERS, BARRIERS and BARRIERS SQ, and to allow the effect of PATH AREA to be visible in the model, the latter three were not included. Finally (V), we tested the effect of air pollution, as signified by the index variable pollution, which indicates stress symptoms of Picea abies on spruce dominant sites. It has the benefit of being a robust indicator on an ordinal scale, reflecting the same overall spatial pattern as indices based on e.g. the condition of epiphytes and heavy metal accumulation in the humus layer (Pihlström et al. 1994), but it is also subject to criticism, as it may depend on factors other than air pollutants (for example, fragmentation). To minimise the risk of confusing the effect of another factor with that of polution, this variable was tested within a full model adjusting for all the other hypothesised factors.

The reader should be aware that an observational sampling design such as that used here, does not allow as strict testing as a manipulative experimental set-up would. Many ecological studies cannot - for various reasons - be conducted experimentally, and often the epistemic status of the results remains obscure. Here, we want to show how, despite the observational design,
Table 1. Operationalization of the hypotheses using multiple regression models ( $T$ indicates prediction of a positive elfect. $I$ of a negative one). For description of variables see text and Table 2.

\begin{tabular}{|c|c|c|c|}
\hline & Hypothesis & Variables used & Adjusting variable \\
\hline 1 & $\begin{array}{l}\text { Available regenera- } \\
\text { tion sources }(\uparrow) \\
\text { Growing space }(\uparrow) \\
\text { Fragmentation }(\uparrow \downarrow)\end{array}$ & $\begin{array}{l}\text { PARENTS } \\
\text { PARENTS SQ } \\
\text { OTHER TREES } \\
\text { FOREST AREA }\end{array}$ & $\begin{array}{l}\text { BARRIIRS } \\
\text { BARRIERS SO } \\
\text { PATII ARLA }\end{array}$ \\
\hline II & $\begin{array}{l}\text { Wear (recreational } \\
\text { pressure: } 1 \text { ) } \\
\text { Safe sites ( } 1 \text { ) }\end{array}$ & $\begin{array}{l}\text { USERS } \\
\text { BARRIERS } \\
\text { BARRIERS SQ }\end{array}$ & $\begin{array}{l}\text { PARLNTS } \\
\text { PARLNTSO } \\
\text { OthER TREFS } \\
\text { Forest area }\end{array}$ \\
\hline HI & $\begin{array}{l}\text { Authropogenic } \\
\text { disturbance other } \\
\text { than wear }(1 \downarrow)\end{array}$ & USERS & $\begin{array}{l}\text { PAREATS } \\
\text { PARENIS KO } \\
\text { OTHER TRIES } \\
\text { FORLET AKEA } \\
\text { PATH AREA }\end{array}$ \\
\hline IV & Actual wear ( $($ ) & PAHHAREA & $\begin{array}{l}\text { PARENTS } \\
\text { PARENTS } 50 \\
\text { OTHER TRFES } \\
\text { POREST AREA }\end{array}$ \\
\hline $\mathrm{V}$ & Air pollution $(\uparrow \downarrow)$ & POLLUTION & $\begin{array}{l}\text { PAREYTS } \\
\text { PARLETS SQ } \\
\text { OHHER TRFES } \\
\text { FOREST RRISA } \\
\text { BARRIEKS } \\
\text { BARRIERS SO } \\
\text { USERS } \\
\text { PATH AREA }\end{array}$ \\
\hline
\end{tabular}

with the a priori approach one can test hypotheses instead of settling for fuzzy exploration. Simply. a priori hypotheses are tested because a possibility for rejection exists (Cook \& Campbell 1979). We have used statistical controlling to overcome the lack of manipulation: testing each variable in a carefully a prior $i$ defined model provides a much more severe test than the ordinary one-model regression procedure (Hinkelmann \& Kempthorne 1994). Further, we did not just test many models once, but tested each model against seven response variables, which allowed us to see whether reasonable patterns existed in the results.

\section{Exploration of data}

In a best subset regression (software Statistix 7: Anon. 1996), we took advantage of more refined data that was not used in the above tests. The independent variables used in a priori tests were divided into components, to explore the effect of the size and species of trees, type of structural elements, such as microsites. size of forest area and distance from the forest edge. different groups of potential recreationists and levels of actual wear (Table 2). Data on the forest compartments from the Green Area Divisions were used to check for effects of the dominant tree layer on regeneration. 
Table 2. Description of the variables used in the analysis.

\begin{tabular}{|c|c|c|c|c|}
\hline Effect & & Variable & Abbreviaton & Unit \\
\hline $\begin{array}{l}\text { Regencration } \\
\text { sources. } \\
\text { available } \\
\text { growing space, } \\
\text { relationships } \\
\text { between species }\end{array}$ & $\begin{array}{c}2 \\
3 \\
4 \\
5 \\
6 \\
7 \\
8 \\
9 \\
10 \\
11 \\
12 \\
13 \\
14\end{array}$ & 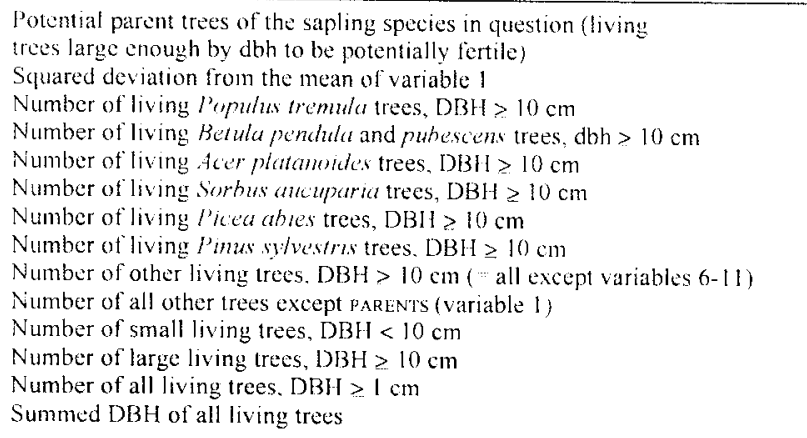 & $\begin{array}{l}\text { OTHER SPECHES } \\
\text { OTHER TREES } \\
\text { SMALL TRETS } \\
\text { LARGE TRIES } \\
\text { DHH OF INING TREES }\end{array}$ & $\begin{array}{l}\text { count } 100 \mathrm{~m}^{2} \\
\text { count } 100 \mathrm{~m}^{2} \\
\text { count } 100 \mathrm{~m}^{2} \\
\text { count } 100 \mathrm{~m}^{2} \\
\text { count } 100 \mathrm{~m}^{2} \\
\text { count } 100 \mathrm{~m}^{2} \\
\text { count } 100 \mathrm{~m}^{2} \\
\text { count } 100 \mathrm{~m}^{2} \\
\text { count } 100 \mathrm{~m}^{2} \\
\text { count } 100 \mathrm{~m}^{2} \\
\text { count } 1100 \mathrm{~m}^{2} \\
10 \mathrm{~cm} / 100 \mathrm{~m}^{2}\end{array}$ \\
\hline $\begin{array}{l}\text { Characteristics } \\
\text { of the dominant } \\
\text { tree layer }\end{array}$ & $\begin{array}{l}15 \\
16 \\
17 \\
18\end{array}$ & $\begin{array}{l}\text { Age of the dominant tree layer } \\
\text { Mean diameter of the dominant tree layer } \\
\text { Stem number of the dominant tree layer } \\
\text { Basal area of the dominant tree layer }\end{array}$ & AGiE: & $\begin{array}{l}\text { yr } \\
\mathrm{cm} \\
\text { counthat } \\
m^{2} / \text { ha }\end{array}$ \\
\hline $\begin{array}{l}\text { Available } \\
\text { growing space. } \\
\text { available } \\
\text { sate sites }\end{array}$ & $\begin{array}{l}19 \\
20 \\
21 \\
22 \\
23\end{array}$ & $\begin{array}{l}\text { Number of all dead trees } \\
\text { Number of dead trees. dbh }>5 \mathrm{~cm} \\
\text { Summed DBH of all dead trees } \\
\text { Summed length of fallen trees forming barriers higher than } 30 \mathrm{~cm} \\
\text { Coarse woody debris (- variables } 21+22 \text { ) }\end{array}$ & $\begin{array}{l}\text { DBH OF DFAD TREFS } \\
\text { FAA L.FN TREFES } \\
\text { CWD }\end{array}$ & $\begin{array}{l}\text { count } 100 \mathrm{~m}^{2} \\
\text { count } 100 \mathrm{~m}^{2} \\
\operatorname{com} 100 \mathrm{~m}^{2} \\
\mathrm{~m} 100 \mathrm{~m}^{2} \\
\mathrm{~m} 100 \mathrm{~m}^{2}\end{array}$ \\
\hline $\begin{array}{l}\text { Barriers against } \\
\text { wear available } \\
\text { safe sites, } \\
\text { growing space }\end{array}$ & $\begin{array}{l}2-4 \\
25 \\
26\end{array}$ & $\begin{array}{l}\text { Summed diameter of stones, height } \geq 30 \mathrm{~cm} \\
\text { Summed width of topographic elements, height } \geq 30 \mathrm{~cm} \\
\text { Summed width of miscellaneous structures (ant nests, bushes. } \\
\text { anthropogenic structures), height } \geq 30 \mathrm{~cm} \\
\text { All barriers ( }- \text { variables } 21+22+24+25+26 \text { ) } \\
\text { Squared deviation from the mean of variable } 27\end{array}$ & 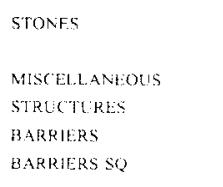 & $\begin{array}{l}\mathrm{m} / 100 \mathrm{~m}^{2} \\
\mathrm{~m} / 100 \mathrm{~m}^{2} \\
\mathrm{~m}: 100 \mathrm{~m}^{2} \\
\mathrm{~m}: 100 \mathrm{~m}^{2}\end{array}$ \\
\hline $\begin{array}{l}\text { Frugnentation. } \\
\text { edge offect }\end{array}$ & $\begin{array}{l}29 \\
30 \\
31\end{array}$ & $\begin{array}{l}\text { Size of forest area including the study site, } \log _{10} \\
\text { Distance to the nearest forest edge, } \log _{111} \\
\text { Inhabitants within } 500 \text { m distance from the center of the study site } \\
\text { (Helsinki City regional database: Vuori } 1998 \text { ). }\end{array}$ & $\begin{array}{l}\text { FOREST ARLEA } \\
\text { LDGE DISTANCE } \\
\text { INIAABTA NTS }\end{array}$ & hat \\
\hline $\begin{array}{l}\text { Recreational } \\
\text { pressure }\end{array}$ & 33 & $\begin{array}{l}\text { Children at schools and kindergartens within } 300 \text { m distance from the centre } \\
\text { of the study site (Helsinki City regional database; Vuori 1998). } \\
\text { Potential recreationists (: variables } 31+32 \text { ) }\end{array}$ & $\begin{array}{l}\text { CHLLDREN } \\
\text { USERS }\end{array}$ & $\begin{array}{l}190 \text { individuals } \\
100 \text { individuals }\end{array}$ \\
\hline Actual wear & $\begin{array}{l}34 \\
35\end{array}$ & $\begin{array}{l}\text { Path arca 1, vegetation damaged, but only little reduced in cover } \\
\text { Path area } 2-4, \text { stronger wear, vegetation damaged and reduced in cover or } \\
\text { completely worn out; sometimes stones and tree roots uncovered. bare } \\
\text { mineral ground or a deep trail dug by trampling } \\
\text { Total area of spontaneous paths (= variables } 34+35)\end{array}$ & PATH AREA & $\begin{array}{l}m^{2} / 100 m^{2} \\
m^{2} / 100 m^{2}\end{array}$ \\
\hline Arr pollution & 37 & $\begin{array}{l}\text { Index variable ind needle loss, defoliation of the bases of branches and } \\
\text { growth of secondary twigs of Picea abies (Niskanen 1996) }\end{array}$ & POILUTIU: & classes $1-3$ \\
\hline
\end{tabular}

\section{Results}

\section{Amount of regeneration}

We identified saplings of 23 woody taxa capable of growing at least $2 \mathrm{~m}$ high; most saplings were Sorbus cucuparia (Table 3). There was a marked change in dominance and a decrease in the number of species with increasing size (Fig. 1).

Stem diameter distributions were skewed to the right, i.e. there were many saplings and a decreasing number of individuals with increasing size (Fig. 2). The group 'other species' included one individual of Alnus glutinosa with a dbh of $10 \mathrm{~cm}$. The rest of this group were present as a few individuals of 1 or $2 \mathrm{~cm} \mathrm{dbh}$ (Amelanchier spp., Jumiperus communis and Prumus domestica) or only as saplings (cf. Table 3).

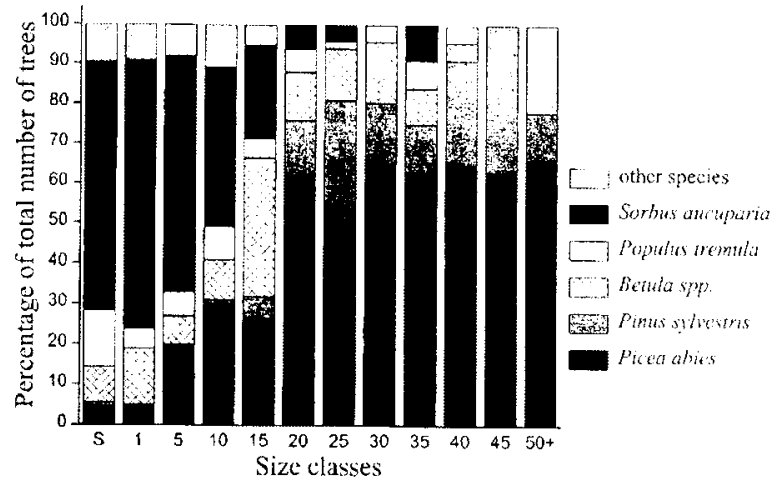

Fig. 1. Proportions of different tree species in different sizo classes ( $\mathrm{x}$-axis). $\mathrm{S}=$ saplings: $1=$ individuals with dbh $\mathrm{I}-4$ $\mathrm{cm} ; 5=$ individuals with dbh $5-9 \mathrm{~cm}$. etc. 
Table 3. Mean, standard error of mean. minimum and maximum for number of saplings $(30-200 \mathrm{~cm}$ high $)$ per $100 \mathrm{~m}^{2}$ in urban woodlands of Helsinki and Vantaa. Frequency gives the number of stands where the species was observed.

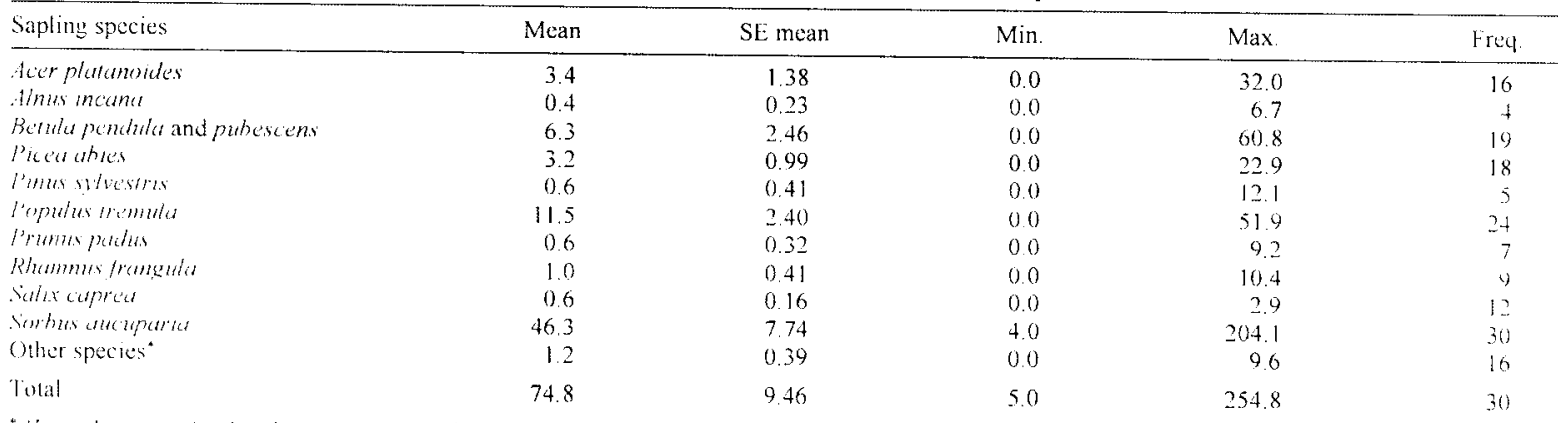

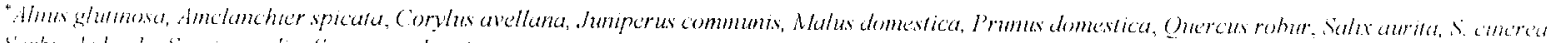

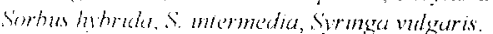

\section{The a priori hypotheses}

The estimation results for the regression models are given in Table 4 . The adjusted coefficients of determination $\left(R^{2}\right)$ across the models were highest for $A c e r$ platanoides. For most response variables, the highest or second highest $R^{2}$ was for model IV.

The number of saplings increased together with PAR-
ENTS as hypothesized (I). When the number of parent trees increased above a certain level, all models except the one for Picea abies showed a decrease or a retarded increase in sapling number, signified by PARFNTS SQ. OTHER TREES did not show any trend. The effect of fragmentation on regeneration (I) was supported by the results: the coefficient of FOREST AREA was negative for all except Picea abies and the other species group.

Table 4. Fstimation results of the regression models used to test the a priori hypotheses I-V (with $95 \%$ confidence intervals). The parameter estimates are given as percentage change in the number of saplings with respect to one unit increase in the explanatory variable. Coefficients with $p \leq 0.05$ are indicated with bold font, those with $0.05<p \leq 0.10$ with normal font. The markings $<0$ and $>0$ are used when $0.10<p \leq 0.20$ and they indicate the direction of the effect. Estimates with $p>0.2$ are not shown. n $n 29$

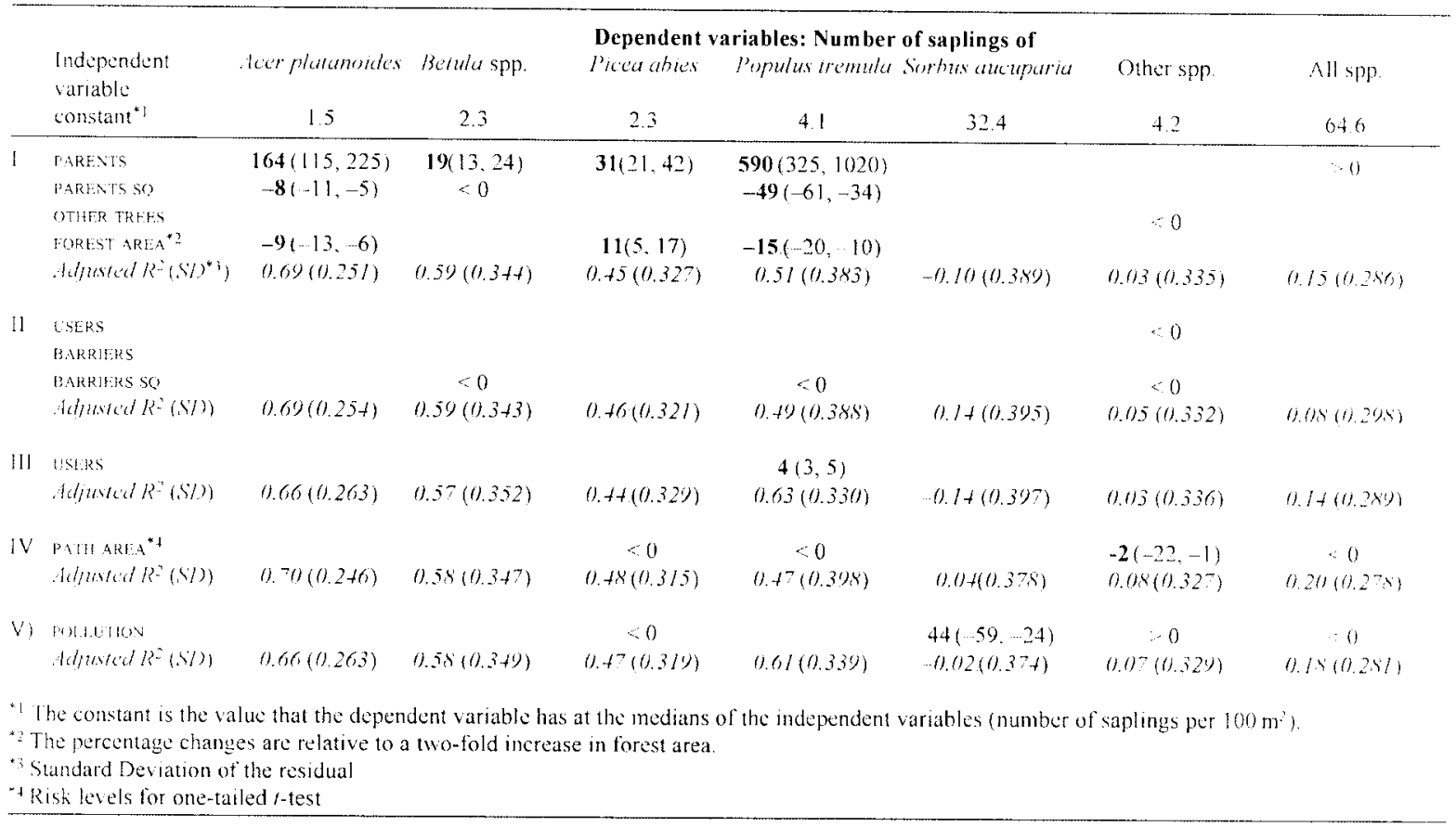

Electronic version of the proofs of Journal of Vegetation Science manuscript No. 2254 by Lehvävirta, S. \& Rita, 10 pp., to be published in Vol. 13, 2002 Not to be distributed for purposes other than proof-correction. 

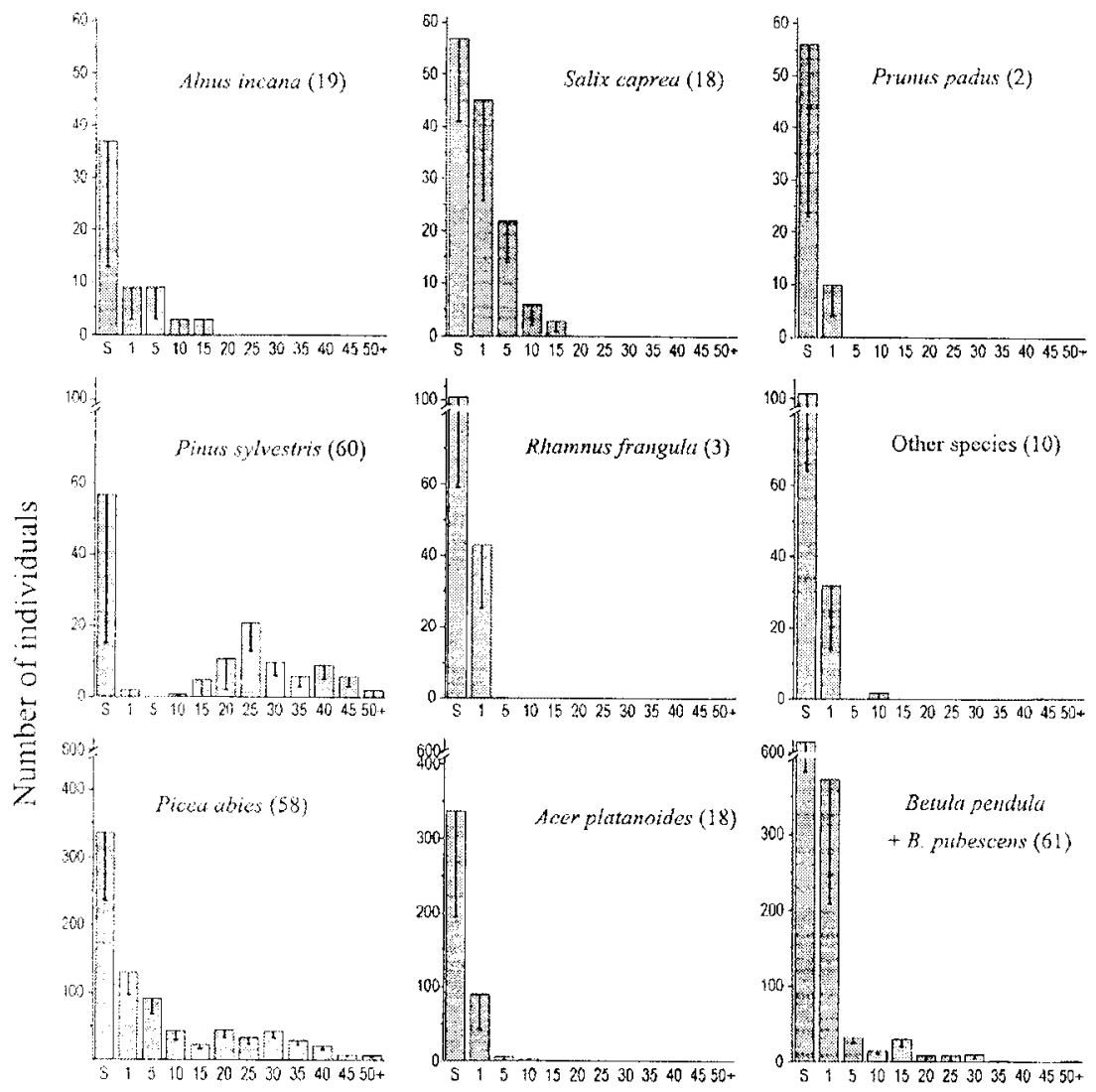

Fig. 2. Stem diameter distributions (mean of the number of individuals per ha across the 30 sites) of the 10 most common tree species. other species pooled and the total number of individuals. The largest diameters $(\mathrm{cm}$ at $\mathrm{dbh})$ are given in parentheses. Error bars show the standard crror of mean. Note scale differences on y-axes. For detinition of size classes see the legend of Fig. 1

Contradictory to our expectations wear, as measured indirectly (II), was not a good predictor of regeneration success. Further model specification showed that the effect of IsIRS was masked by FOREST AREA without which the negative effect of (jSE:Rs became more visible. Moreover, isI:RS had a positive coefficient for each deciduous taxon, when adjusted for FOREST AREA and PATH AREA (III). The effect was strongest for Populus Iremula: an increase of 100 in USERS corresponded an increase of $4 \%$ in the number of saplings. Usually, BARRIFRS had a positive regression coefficient, while BARRIERS SQ had a negative one, indicating a decrease in sapling number after a certain amount of barriers.

Wear, measured directly as PATH ARLA (range 0$79.6 \mathrm{~m}^{2} / 100 \mathrm{~m}^{2}$ ), had a negative effect on all of the response variables, which supported our hypothesis IV,

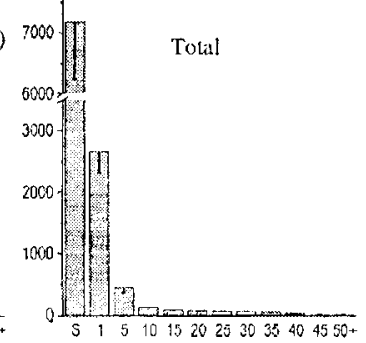

despite several large $p$-values of individual $t$-tests. A one unit increase in PAFII AREA (i.e. percentage of trampled area increase by one unit, for example, $1 \mathrm{~m}^{2} / 100 \mathrm{~m}^{2}$ ) corresponded to a decrease of $1-2 \%$ in the number of saplings.

Pollution (V) had a negative regression coefficient in all models, except for the other species group.

\section{Data exploration}

The models developed with the best subset regression are shown in Table 5 (see Table 2 for the list of independent variables and their abbreviations). The effect sizes should not be looked at as hard evidence, but merely as hints on the relative importance of different effects for further studies. 
Table 5. Parameter estimates (with 95\% confidence intervals) of the best subset regression models used in developing the a posteriori hypotheses. For interpretation of values, see Table 4.

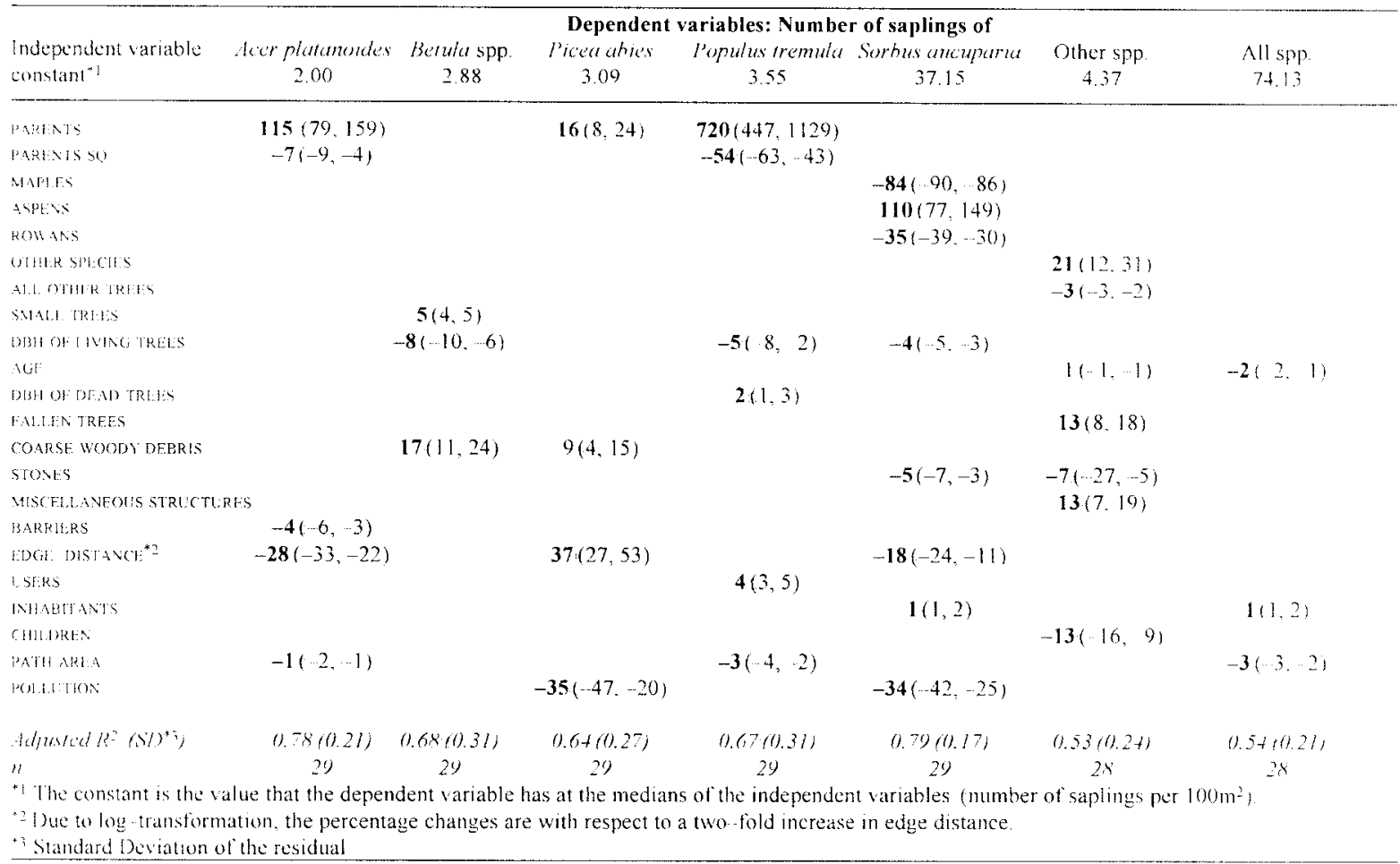

The positive effect of regeneration sources was again obvious for most sapling species, as shown by the positive effect of PARENTS and larger $(\mathrm{dbh} \geq 10 \mathrm{~cm})$ source trees. This eliminated the possibility of having confused vigorous regeneration (a lot of small parent trees) with regeneration sources for a priori hypothesis testing. For Sorbus aucuparia and Betula spp., however, PARLXIS was rather an indicator of continuous regeneration, as the larger source trees had a negative coefficient. Otherwise individual tree species $(\mathrm{dbh} \geq 10 \mathrm{~cm})$ did not show general trends in their effects on the number of saplings.

The positive coefficient of DBH OF DEAD TRELS and the negative coefficients of PARENTS SQ, LARGE TREES, dbh OF I.IVING TREES and AGE, suggested that available growing space mattered. Furthermore, the fact that SMALL TRELS had positive coefficients during all best subset procedures, revealed why the OTHER TREES variable in the tested models was not a good indicator of growing space: it also indicated vigorous regeneration that had just passed the sapling stage, as it included small trees.

Data exploration supported the existence of an effect of FORLST AREA on the number of saplings. However, EIXCEE DISIANCE was clearly a better predictor in the final models, suggesting that distance from the forest edge was more important than the size of forest area as such. Increase in FICIE DISTANCE had a negative effect on the number of all saplings except Picea abies and the other species group.

An increase in INHABITANTS had a positive effect on the numbers of Populus tremula. Betula spp. and Sorbus aucuparia saplings and for all species pooled, but only P. tremula and Betula spp. flourished near schools and kindergartens. An increase in area of even the most lightly worn paths (Table 2) had a negative effect on the response variables, and $\mathrm{PATH}_{\mathrm{AREA}} \mathrm{W}$ was included in three models.

FALLEN TREES Or COARSE WOODY DEBBIS usually had a positive effect on the number of saplings. Only deer platanoides did not benefit from the presence of any sort of dead wood. COARSE WOODY DEBRIS was modelled to increase the number of Betula spp. and Picea abies saplings by 17 and $9 \%$, respectively, for an increase of $100 \mathrm{~m} /$ ha in COARSE WOODY DI:BKIS. STONIS had a negative effect on the number of saplings, except for Betulc spp. and $P$. abies.

A possible effect of PoLLuTION was also supported by the results of the best subset regression. It had a negative effect on all the sapling species except Acer platanoides and the other species group. 


\section{Discussion}

\section{Past and present regeneration}

All the commonest tree species were present as saplings and small trees, indicating good regeneration potential. The numbers of saplings were comparable to those in rural woodlands (Leemans 1989; Kuuluvainen 1994 and references therein). Size distributions of Picea abies, Pinus sy/restris and deciduous trees resembled those of comparable sites in southern Finland (Lähde et al. 1991). However, in our study area, a larger proportion of regeneration consisted of deciduous species, particularly Sorbus aucuparia (Table 6).

Only 6 species made up the size classes from 20 to $40 \mathrm{~cm}(\mathrm{dbh})$, though other tall-growing species (i.e. Acer platanoides, Salix caprea, Prumus padus, Alnus incana. Quercus robur) were present as saplings or small trees. Kubota \& Hara (1996) observed differentiation of regeneration patterns among species in a subboreal forest in Japan. Our a posteriori results suggest the same phenomenon, as the hypothetical models about factors affecting regeneration are different for each species. A follow-up study would be interesting in order to see which species of the regenerated stock will form the future canopy layer.

\section{Factors affecting regeneration in urban woodlands}

The importance of regeneration sources for regrowth was predictable, as sprouting and seed rain from trees at the site are known to strongly contribute to regeneration (Johnson et al. 1981; Ranney et al. 1981; Zasada et al. 1992). Apparently, growing space matters too, but a more exact measure than the number of other living trees is needed. Based on a posteriori exploration. the summed dbh of all living trees seemed useful. This parallels the results of Kubota \& Hara (1996), who used the summed basal area of all trees ( $\geq 2 \mathrm{~m}$ tall) to explain recruitment of saplings into the tree layer. The negative effect of age may be due to a decrease in available growing space due to canopy closure and increasing root competition. This cannot be interpreted outside the narrow age range in our data, as the effect may differ according to the age of the dominant tree layer.
Levenson (1981) and Ranney et al. (1981) suggested that light and wind penetration that depend on woodland island size, shape, orientation and width, might affect tree species composition. These climatic factors could be a reason for the observed decrease in Picea abies and increase in Populus tremula and Sorbus aucuparia saplings towards the woodland edge. However, the same explanation is not likely for the increase in Acer platanoides saplings towards the edge as the species can withstand shade. Instead, increase in soil nitrogen and $\mathrm{pH}$, together with seed rain from $A$. platanoides in parks and along streets, may play a role here (cf. Sachse et al. 1990; Kurtto \& Helynranta 1998).

The negative effect of wear (Tonnesen \& Ebersole 1997; Bhuju \& Ohsawa 1998) gained support, as path area affected the number of saplings negatively in all models. The number of people in the vicinity of a study site was not a good indicator of wear. First. it was partly confounded with woodland size and distance from the edge, and second, anthropogenic disturbance had some positive effects, most clearly on Populus tremula and Sorbus aucuparia saplings. Interestingly, the positive effect was not a by-product of edge effect or seedbed preparation by wear. It could be due to, for example, fertilization by excrements from domestic animals and the formation of new substrates (Bullock \& Gregory 1991; Shaw et al. 1995).

Tonnesen \& Ebersole ( 1997) showed that. in heavily trampled areas, spots which are protected by rocks and woody plants, may retain their regeneration ability. Our study sites were less worn, which may partly explain why pooled structural elements suggested only a slight positive effect. Furthermore, different barriers do not form equally good recruitment sites (Zasada 1992). In the first place, fallen trees are indicative of released growing space and offer favourable microsites for regrowth (Hofgaard 1993: Kuuluvainen 1994) but, in the most worn-out woodland areas, they may also limit wear (Lehvävirta 1999). Our hypothetical result about the positive effect of decaying wood on regeneration would be worth testing, as it parallels findings in rural boreal forests, and because the same idea has been presented elsewhere too, e.g. for an urban woodland in New York City (Rudnicky \& McDonnell 1989).

The concentration of air pollutants such as nitrogen

Table 6. Tree species in urban (our study sites) and rural (Lähde 1992) woodlands (\% of total number).

\begin{tabular}{|c|c|c|c|c|c|}
\hline & Sire classes & $\begin{array}{l}\text { P'icea ahies and } \\
\text { l'imes sverestris }\end{array}$ & Betula spp & $\begin{array}{c}\text { Other spp } \\
\text { (incl Sorbus ancuparia) }\end{array}$ & Sorbus azcupurw \\
\hline Our study sites & Saplings $30-200 \mathrm{~cm}$ & 6 & 9 & 85 & 62 \\
\hline \multirow[t]{2}{*}{ (.ihde (1992) } & Seedlings and saplings $10-130 \mathrm{~cm}$ & 58 & 8 & 36 & \\
\hline & Undergrowth $131-350 \mathrm{~cm}$ & 42 & 38 & 20 & \\
\hline
\end{tabular}

Electronic version of the proofs of Journal of Vegetation Science manuscript No. 2254

by Lehvävirta, S. \& Rita, 10 pp., to be published in Vol. 13,2002

Not to be distributed for purposes other than proof-correction. 
compounds, sulphur dioxide and ozone, still exceed acceptable levels in Helsinki and Vantaa, though sulphur and nitrogen levels are declining (Niskanen \& Ellonen 1998). According to our results, air pollution may have a negative effect on regeneration of trees, particularly Picea ahies and Sorbus ancuparia. This is in accordance with Larcher (1995), who suggests Picea spp. to be relatively sensitive to air pollutants. However, $S$ aucuparia has been claimed to be quite tolerant (Hawrys 1984; Supuka 1992). Our results are speculative because, even though our measure of air pollution showed the same areal pattern as other indicators of pollution, it is possible that the observed pattern was due to a confounding effect, for example climatic changes towards the city centre. The question about the effect of air pollution on urban woodlands has been raised before (e.g. Rudnicky \& McDonnell 1989), but still lacks reliable answers.

\section{Suggestions for planning and management}

The regeneration of natural urban woodlands is usually adequate to ensure continuity, but tree species assemblages may change in the long term, as various anthropogenic factors affect different species differently. Here, the strongest of these factors were fragmentation (emphasising edge effect) and wear.

The size and shape of a woodland is of concern when attempting to preserve a viable $P$. abies population. Though fragmentation did not have a negative effect on other species, there may be indirect effects from the loss of woodland area. Firstly, the loss of area may result in more intensive use and wear of the remnant patches. Secondly, transfer of material (e.g. dust, seeds and pathogens) into the remaining stands may increase and interfere with essential processes (reviewed by Saunders et al. 1991).

In areas suffering from air pollution or intensive recreational use, regular thinning seems unwise, as dense stands may be more sustainable against pollution (Norokorpi \& Frank 1993) and wear (Lehvävirta 1999). Furthermore, our hypothesis about the detrimental effect of lack of fallen trees may apply generally, as studies in different forest ecosystems show that fallen trees can act as 'nurse logs' (Hofgaard 1993; Kuuluvainen 1994: Silvertown 1992) and possibly as natural barriers against wear.

Acknowledgements. Helsinki and Vantaa Cities provided data. Jonna Niemenmaa assisted with the fieldwork. Arto Kurtto helped with the identification of difficult sapling specimens. Johan Kotze and Jari Niemelä gave valuable comments on the manuscript. and Stephen Venn corrected the language. Financial support was provided by the Jenny and Antti Wihuri Foundation and ECOPL $\Lambda N$ (project number 39715) of the f'innish Biodiversity Research Program.

\section{References}

Anon. 1996. Statistix for Windows. Users mantal. Analytical Software. Tallahassee, $\mathrm{H} 1$

Anon. 1998. Helsinki Region Statistics. http:/helno3.novogroup.com/asarjat/

Ahti. T.. Hämet-Ahti, L. \& Jalas. J. 1968. Vegetation rones and their sections in north-western kurope. Inn. Bot Fenn. 5: 169-211.

Bader, P.. Jansson, S. \& Jonsson, B.G. 1995. Wood-inhabiting fungi and substratum decline in selectively logged boreal spruce forests. Biol. Conserv. 72: 355-362.

Bhuju. D.R. \& Ohsawa, M. 1998. Effects of nature trails on ground vegetation and understory colonisation of a patehy remnant forest in an urban domain. Biol. Consem. 85 123-135.

Breuste. J.. Feldmann, H. \& Uhlmann. O. (eds.) 1998. Urhan Ecology. Springer-Verlag. Berlin. DE.

Bullock, P. \& Gregory, P.J. (eds.) 1991. Soils in the urtom environment. Blackwell. Oxford, UK

Cook. T. \& Campbell. D. 1979. Ouasi-experimentation. Design and analysis issues for field settings. Houghton Mifflin. Boston. MA

Hämet-Ahti. L., Palmén. A.. Alanko. P. \& Tigerstedt. P.M.A 1992. Woody Flora of Finkand. Dendrologian Seura. I lelsinki. FI. (In Finnish with English summary.)

Hawrys, Z. 1984. Sensitivity of some deciduous trees to sulphur compounds and heary metals. Lkol. Pol. 32: 103-124.

Heliövaara, K. \& Väisänen, R. 1984. Leffects of modem forestry on northwestern European forest invertehrates: a synthesis, Acta For. Fenn. 189: 1-32.

Hinkelmann, K. \& Kempthorne, O. 1994. Design and analysis of experiments: Volume I: Introduction to experimental design. Wiley. NewYork, NY.

Hofgaard. A. 1993. Structure and regeneration patterns of : virgin Picea abies forest in northern Sweden. J. Feg. Sci. 4: $601-608$

Johnson, C.V., Sharpe. D.M., DeAngelis. D.L.. Fields. D.L. \& Olson. R.J. 1981. Modeling seed dispersal and forest island dynamics. In: Burgess, R.L. \& Sharpe. D.M. (eds.) Forest island dynamics in man-dominated landscapes, pp. 215-239. Springer-Verlag. New York. NY.

Kerlinger, F.N. 1986. Foundations of behavioural research. Holt, Rinehart \& Winston, Orlando. Fl.

Konijnendijk. C.C. 1997. A short history of urban forestry in Europe. J. Arboric 23: 31-39

Kubota, Y. \& Hara. T. 1996. Reeruitment processes and species coexistence in a sub-boreal forest in northem Japan. Ann. Bot. 78: 741-748.

Kurto. A. \& Ilelynanta. L. 1998. Flora of Helsinti. From flowering stones to forest floor. Helsinki University Press. Helsinki, Fl. (In Finnish with Finglish summary.)

Kuuluvainen, T. 1994. Gap disturbance, ground microtopography, and the regeneration dynamics of boreal coniferous forests in Finland: a review. Ann. \%ool. Fenn. 31: 35-51.

Kuuluvainen. T., Hokkanen. T.J., Järvinen. I. \& Pukkala. T. 1993. Factors related to seedling growth in a borcal Scots pine stand: a spatial analysis of a vegetation-soil sy stem. Can. J. For. Res. 23: 2101-2109 
Laahde. F. 1992. Regeneration potential of all-sized sprucedominated stands. Swed. Univ. Agric. Sci. Dept. Silvic. Rep. 35: 111-113.

1.ahde. B.. Laiho. O.. Norokorpi, Y. \& Saksa, T. 1991. The structure of advanced virgin forests in Finland. Scand. J. For. Res. 6: 527-537.

Larcher. W. 1995. Phwsiological plant ecologv: SpringerVerlag. Berlin. DLt.

I.cemans. R. 1989. Description and simulation of stand structure and dynamics in some Swedish forests. Ph.D. Disserlation. Heta Univ. Ups. 221: 1-44.

l.chvävirta. S. 1999. Structural elements as barriers against wear in urban woodlands. Urban Ecosyst. 3: 45-56.

Levenson. I.B. 1981. Woodlots as biogeographic islands in souheastern Wisconsin. In: Burgess, R.L. \& Sharpe, D.M reds.). Forest island dynamics in man-dominated landscapes, pp. 13-39. Springer-Verlag. New York. NY.

L indholm. T. \& Tuominen, S. 1993. Metsien puuston luonnontilan arviointi. Metsähallituksen luonnonsuojehijulkaisuja $\Lambda(3)$ : 1-40. (In Finnish.)

McDonnell. M.J. \& Pickett, S.T.A. 1990. Ecosystem structure and function along urban-rural gradients: an unexploited opportunity for ecology. Ecology 71: 1232-1237.

McDonnell. M.J.. Pickett. S.T.A.. Groffman. P.. Bohlen, P.. Pouyat. R.V.. Zipperer. W.C., Parmelee, R.W., Carreiro. M.M. \& Mcdley. K. 1997. Ecosystem processes along an urban-to-rural gradient. Urban Ecosyst. 1: 21-36.

Nicmelii. I. 1997. Invertebrates and boreal forest management. Conserv. Biol. 11:601-610.

Niemelä..1. 1999. Fcology and urban planning. Biodiv. Conserv. 8: $119-131$

Niskanen. 1. \& Ellonen. T. 1998. Bioindicator study of air quality in the Helsinki Metropolitan Area year 1998 Pääkaumunkiseudun inilkaisusaria PJS C 1998(12): 1-59. (In linnish with linglish abstract.)

Niskanen. I. Veijola. H. \& Ellonen. T. 1996. Bioindicator study of air quality in the Helsinki Metropolitan Area year 1996. Päakcaupunkiseudun julkaisusarja PJS C 1996(17): 1-46. (In Finnish with English abstract.)

Norokorpi. Y. \& Frank, H. 1993. Effect of stand density on damage to birch (Betula pubescens) caused by phytotoxic air pollutants. Ann. Bot. Fenn. 30: 181-187.

Oliver, C.D. \& Larson, B.C. 1996. Forest stand dynamics. John Wiley \& Suns. Inc. New York. NY.

Pihlström. M.. Mäkinen, A.. Hämekoski, K.\& Ruuhijärvi. R. 1994. Bioindicator study of air quality in the Helsinki Metropolitan Area years 1988-1993. Päökaupunkiseudun julkaisusarja PJS C 1994(9):1-139. (In Finnish with English abstract.)

Prus-Cilowacki. W. \& Godzik. St. 1991. Changes induced by finc smefter pollution in the genetic structure of pine (Pinus sylvestris L.) secdling populations. Silvae Genet 40: $184-188$

Ranney, I.W. Bruner M.C. \& Levenson, J.B. 1981. The importance of edge in the structure and dynamics of forest islands. In: Burgess. R.L. \& Sharpe, D.M. (eds.) Forest island dynamics in man-dominated landscapes, pp. 67-95. Springer-Verlag. New York. NY.
Rassi, P. \& Väisänen. R. (eds.) 1987. Threatened animals and plants in Finland, English summary of the report of the Committee for the Conservation of Threatened Animals and Plants in Finland. Ministry of the linwironment. Committee report $1985(30)$ ): $1-82$.

Rebele, F. 1994. Urban ecology and special features of urban ecosystems. Global Ecol. Biogeogr. Lett. 4: 173-187.

Renvall, P. 1995. Community structure and dynamics of woodrotting Basidiomycetes on decomposing conifer trunks in northern Finland. Karstenia 35: 1-51

Rydberg, D. \& Falck, J. 1998. Utban forestry in Sweden from a silvicultural perspective: A review. Acta Lmw. fgric. Sulaec. Silv. 73: 1-23

Sachse. U.. Startinger, U. \& Kowarik. 1. 1990. Synanthropic woody species in the urban area of Berlin (West). In Sukopp, H., lejný. S. \& Kowarik. I. (eds.) Lrban écolog): Plants and plant communities in urban environments. pp. 232-243. SPB Academic Publishing bv, The Ilague.

Saunders, D.A., Hobbs, R.J. \& Margules. C.R. 1991. Biological consequences of ecosystem fragmentation: A review. Conserv. Biol 5: 18-32.

Scholz. F. 1981. Genecological aspects of air pollution effects on northern forests. Silva Fenn. 15: 384-391.

Shaw, P.J.A., Lankey. K. \& Hollingham. S.A. 1995. Impacts of trampling and dog fouling on vegetation and soil conditions on Headley Heath. London Nat. 1995(74): 77-82.

Silvertown. J.W. 1982. Introduction to plant population ecology. Longman. New York. NY.

Supuka, J. 1992. The effects of deicing salts on the growth and development of Sorbus aucuparia I.. Lesnictvi-forestr. 38: 483-494. (In Crech with English summary.)

Tonnesen. A.S. \& Ebersole, J.J. 1997. Human trampling offects on regeneration and age structures of Pinus edulis and Juniperus monosperma. Great Basin Vat. 57: 50-56.

Tyrväinen. L. 1999. Monetary valuation of urban forest amenities in Finland. Finn. For Res. Inst. Re's. Papers 739: 1 125.

Väisänen. S. 1986. Effects of air pollution by metal, chemical and fertiliser plants on forest vegetation at Kokkola. W Finland. Ann. Bot. Fenn. 23: 305-315

Vuori, P. 1998. Helsinki region areal database. Seutucdaytv fi

Weisberg, S. 1985. Applied linear regression. John Wiley. New York, NY.

Zasada, J.C.. Sharik. T.L. \& Nygren. M. 1992. The reproductive process in boreal forest trees. In: Shugart. H.H. Leemans. R. \& Gordon, B.B. (eds.) A systems analysis of the global boreal forest, pp. 85-125. Cambridge University Press. Cambridge. UK.

Received 22 May 2000 Revision received 10 October 2001 Accepted 22 November 2001 Coordinating Editor: C. Leuschner 